\title{
Effect of Sulphur Application and Saline Irrigation Water on Chemical Properties of Ras Sudr Calcareous Soil, South Sinai, Egypt
}

\author{
Abdallah, A.A*, Mohamed, A.I.**, El-Sikhry, E.M** and Ali, O.M.** \\ * Desert Research Center, Matareya, Egypt \\ ** Soil and Water Dept., Faculty of Agric., Suez Canal Univ., Ismailia 41522, Egypt
}

\section{Received:}

\begin{abstract}
A field experiment was conducted at Ras Sudr, South of Sinai Governorate. The investigated soil was cultivated by wheat (Triticum Vulgare L.). Ras Sudr soil is calcareous in nature and is characterized by high content of $\mathrm{CaCO}_{3}(53.9 \%)$ and total soluble salts $\left(\mathrm{EC}, 29.6 \mathrm{dSm}^{-1}\right)$. The experimental soil was irrigated with a saline ground water $6.18 \mathrm{dSm}^{-1}$ which considered the main source of irrigation water in this area. The effect of irrigation periods $(7,14$ and 21 days), phosphorus application (20,60 $\mathrm{kg} \mathrm{P}_{2} \mathrm{O}_{5} / \mathrm{fed}$.) and sulphur application $(0,100,300,500 \mathrm{~kg} \mathrm{~S} /$ fed.) on the chemical composition of Ras Sudr soil during and after wheat growth season. The EC decreased gradually by increasing $\mathrm{S}$ application and increased progressively by increasing water stress. Sulphur application also decreased soil $\mathrm{pH}$ by $2.5 \%$ relative to the initial $\mathrm{pH}$ value and increased each of soluble-sulphate, available phosphate and potassium.
\end{abstract}

Keywords: Sulphur, Saline water, Irrigation periods, Wheat, Nutrient availability, Calcareous soil

\section{INTRODUCTION}

The horizontal expansion of agricultural lands in Egypt depends on the reclamation of new lands which are mainly in north eastern coastal zone and in Sinai Peninsula. These soils are characterized by high content of $\mathrm{CaCO}_{3}$, alkalinity and salinity which affect to a large extent the availability of several nutrient elements to plants.

Due to insufficient fresh water available to develop all the potential irrigable lands, in this area the use of low quality waters such as underground and drainage waters as well as treated sewage water is a most. The use of such waters is expected to affect salt distribution throughout the soil profile, particularly within the root zone which is of more concern from the agricultural view point. Moreover, the use of low quality water may also cause unfavorable effect on nutrient status beside reversal physical and chemical problems may gradually appear.

The particular structure of calcareous soils is a major problem in farming processes. When they are subjected to irrigation cycle, crust formation occurs at surface, which impedes germination as well as their inadequate water retention and nutrients uptake. Therefore, the application of certain soil amendments for the reclamation of such soils becomes essential.

Most attention has been devoted to use elemental sulphur as a soil amendment for its acidulous effect on increasing the nutrient availability. Therefore, the utilization of elemental sulphur is considered a very important way out in reclaiming and improving the irrigated soils of the arid and semi arid regions.

The present study aimed to investigate the role of sulphur in the availability and uptake of some macronutrients by wheat plant grown in a highly calcareous soil under saline irrigation water conditions of Ras Sudr of Sinai Governorate.

\section{MATERIALS AND METHODS}

A field experiment was conducted in the experimental station of Desert Res. Center at Ras Sudr
South Sinai Governorate, to study the effect of S application on the chemical composition of Ras Surd calcareous soil. The experiment was cultivated with wheat plant (Triticum Vulgare L.), and irrigated by saline water.

Sulphur treatments were $0,100,300$ and $500 \mathrm{~kg}$ $\mathrm{S} /$ fed. $\left(=0,238,714,1190 \mathrm{~kg} \mathrm{~S}^{-1}\right)$ and treated with 30 and $60 \mathrm{~kg} \mathrm{P}_{2} \mathrm{O}_{5} /$ fed. $\left(=47.6,1421.8 \mathrm{~kg} \mathrm{P}_{2} \mathrm{O}_{5} \mathrm{ha}^{-1}\right), 75$ $\mathrm{kgN} /$ fed. as $\mathrm{NH}_{4} \mathrm{NO}_{3}$ and $50 \mathrm{~kg} \mathrm{~K} 2 \mathrm{O} /$ fed. as $\mathrm{KCl}$. The irrigation periods during plant growth were 7, 14 and 21 days. Soil samples were taken at the vegetative, flowering and at harvesting and analyzed for the chemical composition.

\section{Methods of soil and water analysis}

Particle size distribution was determined after Piper (1950). Electrical conductivity (EC), soil $\mathrm{pH}$, total cations and anions were determined in soil paste according to Richards (1954). Total carbonate was determined volumetrically as described by Piper (1950). Organic matter was determined according to Jackson (1958). Gypsum content was determined according to Beaker (1980). Soluble sulfate was determined according to Spencer and Freney (1960). Available-K was extracted by ammonium acetate and determined by a Flamephotometer after Jackson (1958). Available-P was extracted by $0.5 \mathrm{~N} \mathrm{NaHCO}_{3}, \mathrm{pH} 8.5$ according to Olsen et al., (1954) and determined colorimetrically according to Jackson (1958).

\section{RESULTS AND DISCUSSION}

Table 1 shows that Ras Sudr soils have high content of organic matter which reached to $2 \%$. This result may be due to that Ras Sudr soil was used as a pasture for many years. This soil also characterized by high content of salinity $\left(\mathrm{EC}, 29.6 \mathrm{dSm}^{-1}\right)$. This is attributed to that this soil was irrigated for reversal years by ground water which has salinity $>6.18 \mathrm{dSm}^{-1}$, and it is considered the main source of irrigation water.

To study the effect of sulphur application and saline water irrigation on nutrient availability in Ras Sudr calcareous soil, an experiment was conducted in the 
Experimental Station of the Desert Institute at Ras Sudr, South of Sinai Governorate. The experimental soil was cultivated by wheat (Triticum Vulgare L.), which is considered one of strategic crops in Egypt. Tables (2, 3, 4) show the effect of irrigation periods, phosphorus and sulphur applications on some chemical composition of Ras Sudr soil during and after wheat growth season. The results will be discussed under the following headings:

\section{Electrical Conductivity (EC)}

Table 3 shows clearly that, irrespective of phosphate treatments and irrigation periods, the EC decreased gradually in the soil samples taken during wheat growth by increasing sulphur application rate. The reduction in the $\mathrm{EC}$ values reached to $66 \%, 70 \%$ and $72 \%$ relative to the initial EC values for the soil samples taken at vegetative, flowering and after harvesting, respectively. This result may be due to that the high $\mathrm{EC}$ of irrigation water $\left(\mathrm{EC}, 6.18 \mathrm{dSm}^{-1}\right)$. These soluble salts will prevent the dispersion of the soil particles and subsequently enhance the water percolation in soil. This process will facilitate the leaching of soluble salts through the drainage water. Similar conclusion was reported by Rhoades and Invaglson (1969), Pupsky and Shainberg (1979) and Ahmed et al., (2007) who reported that the concentration of salts in irrigation water is very important parameters which affect the hydraulic conductivity and permeability of soils. Also, many investigators such as Stremberg and Tisdale 1979, Ogata and Bower 1975, Dawood et al., 1985, John et al., 1985, Abd El Fattah and Hilal 1985, Ahmed et al., 2007, Fatemeh et al., 2012 found that the addition of elemental sulphur to calcareous soils improved the soil structure and increased hydraulic conductivity and water penetration and subsequently decreased the EC values of soils.

Another reason may be that, the addition of sulphur to calcareous soils may result in increases the gypsum concentration. In this respect, Shadfan and Hussen (1985) found that the X- ray diffraction pattern of the calcareous samples treated with $6000 \mathrm{~kg}^{-1}$ soil sulphur showed gypsum peaks at $0.75 \mathrm{~nm}$. Reda and Modaihish (1990) also found that sulphur application to calcareous soil increased gypsum content in the surface soil layer.

On the other hand, irrespective of sulphur application and irrigation periods, superphosphate treatment increased the EC values in the soil samples which were taken at different stages of wheat growth as shown in Table 4. This may be due to that superphosphate addition to soil will increase the adsorption of cations such as $\mathrm{Ca}^{2+}$ and decrease the adsorption of anions such as $\mathrm{SO}_{4}{ }^{2-}$. Unlike phosphate, $\mathrm{SO}_{4}{ }^{2-}$ is weakly held at the soil surface and is therefore more susceptible to leaching in soil. Thus, phosphate addition will increase the amount of $\mathrm{SO}_{4}{ }^{2-}$ in the soil solution and subsequently increase the EC values. Similar finding was reported by Ryden et al., (1987) and Abdou Soaud et al., (2011).

Regarding to the effect of irrigation periods on the EC values data in Table 4 shows that irrespective of other treatments, the EC values increased progressively by increasing water stress in the soil samples which were taken at different stages of wheat growth. This result was expected because the water stress will reduce the amount of water which will percolate through the soil and subsequently reduce salt leaching. In this respect Marvin (1975) who studied the irrigation scheduling for salinity control found that the irrigation scheduling improved irrigation water management efficiency and reduced salt accumulation in some selected areas.

\section{Soil Reaction (pH)}

Table 4 indicates that irrespective of phosphate treatments and irrigation periods soil $\mathrm{pH}$ was affected especially by high rates treatment. The maximum reduction which reached to $2.5 \%$ relative to the initial $\mathrm{pH}$ values was obtained after harvest by addition of 500 $\mathrm{kg} / \mathrm{fed}$. of sulphur. This slight reduction in different sulphur treatments may be due to the high $\mathrm{CaCO}_{3}$ content of the studied soil. It is known that the soils which have high content of $\mathrm{CaCO}_{3}$ will also have high buffering capacity to change its $\mathrm{pH}$ values. Similar results were obtained by superphosphate treatments as shown in Table (4). In this respect Kashirad and Bazargani (1972), Heter (1985) and Abdou Soaud et al., (2011) found that sulphur as soil amendment for calcareous soils showed insignificant in reducing the $\mathrm{pH}$ value after harvest.

On the other hand, increased the irrigation period slightly increased the $\mathrm{pH}$ values of soil samples at different stages of plant growth as shown in Table 5. It is interesting to note that from the Table 5 that $\mathrm{pH}$ values increased progressively by increasing the EC values.

Table 1 Some physical and chemical properties of investigated Ras Sudr Soil

\begin{tabular}{|c|c|c|c|}
\hline Particle size distribution & & Properties of Ras Sudr soil & \\
\hline Sand (\%) & 68.5 & Available $-\mathrm{P}\left(\mathrm{mg} \mathrm{kg}^{-1}\right)$ & 1.0 \\
\hline Silt (\%) & 15.4 & Available- $\mathrm{K}\left(\mathrm{cmol} \mathrm{kg}^{-1}\right)$ & 10.0 \\
\hline Clay $(\%)$ & 15.9 & Soluble $\mathrm{Ca}^{2+}\left(\mathrm{cmol} \mathrm{kg}^{-1}\right)$ & 1.9 \\
\hline Textural class & Sandy loam & Soluble $\mathrm{Mg}^{2+}\left(\mathrm{cmol} \mathrm{kg}^{-1}\right)$ & 1.1 \\
\hline Organic matter $\left(\mathrm{g} \mathrm{kg}^{-1}\right)$ & 20 & Soluble $\mathrm{Na}^{+}\left(\mathrm{cmol} \mathrm{kg}^{-1}\right)$ & 5.7 \\
\hline Total $\mathrm{CaCO}_{3}\left(\mathrm{~g} \mathrm{~kg}^{-1}\right)$ & 539 & Soluble $\mathrm{K}^{+}\left(\mathrm{cmol} \mathrm{kg}^{-1}\right)$ & 0.1 \\
\hline Gypsum content $\left(\mathrm{g} \mathrm{kg}^{-1}\right)$ & 0.10 & Soluble $\mathrm{HCO}_{3}^{-}\left(\mathrm{cmol} \mathrm{kg}^{-1}\right)$ & 0.1 \\
\hline $\mathrm{pH} *$ & 7.5 & $\mathrm{Cl}^{-}\left(\mathrm{cmol} \mathrm{kg}^{-1}\right)$ & 7.8 \\
\hline $\operatorname{ECe}\left(\mathrm{dSm}^{-1}\right)^{* *}$ & 29.6 & Soluble $\mathrm{SO}_{4}\left(\mathrm{cmol} \mathrm{kg}^{-1}\right)$ & 2.2 \\
\hline
\end{tabular}

\footnotetext{
* In soil-water suspension, ${ }^{* *}$ in soil paste extract
} 


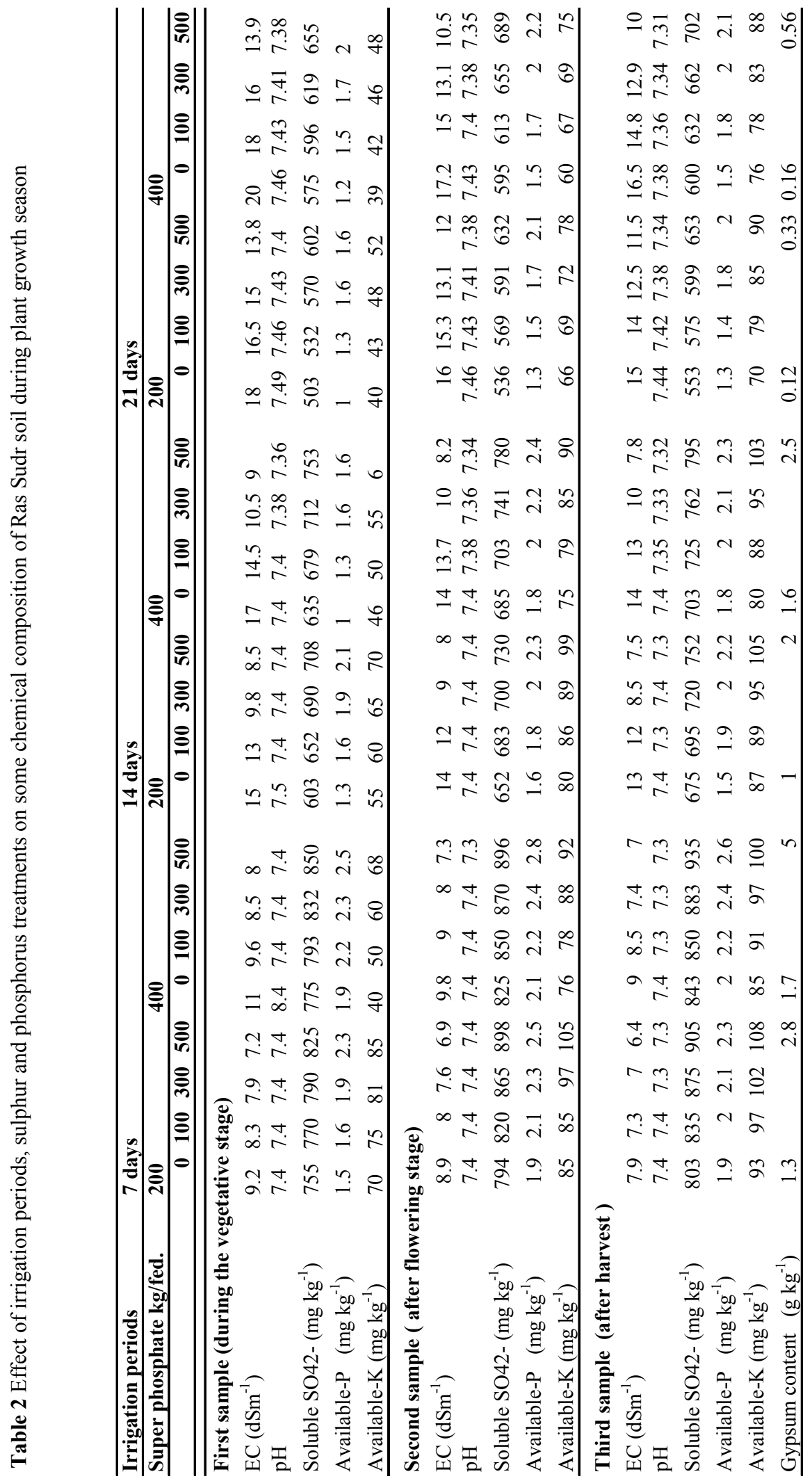


Table 3 Effect of sulphur treatments on some soil characteristics of Ras Sudr soil during growth season and after harvesting

\begin{tabular}{|c|c|c|c|c|c|}
\hline $\begin{array}{l}\text { Sulphur treatment } \\
\text { (kg/fed.) }\end{array}$ & $\begin{array}{l}\mathrm{EC} \\
\left(\mathrm{dSm}^{-1}\right)\end{array}$ & pH & $\begin{array}{l}\text { Soluble } \mathrm{SO}_{4}{ }^{2-} \\
\left(\mathrm{mg} \mathrm{kg}^{-1}\right)\end{array}$ & $\begin{array}{l}\text { Available-P } \\
\left(\mathrm{mg} \mathrm{kg}^{-1}\right)\end{array}$ & $\begin{array}{l}\text { Available-K } \\
\left(\mathrm{mg} \mathrm{kg}^{-1}\right)\end{array}$ \\
\hline \multicolumn{6}{|c|}{ First sample (during the vegetative stage) } \\
\hline 0 & 14.9 & 7.44 & 641 & 1.38 & 48 \\
\hline 100 & 13.2 & 7.42 & 670 & 1.63 & 53 \\
\hline 300 & 11.2 & 7.39 & 702 & 1.88 & 59 \\
\hline 500 & 10.0 & 7.37 & 732 & 2.11 & 63 \\
\hline \multicolumn{6}{|c|}{ Second sample ( after flowering stage) } \\
\hline 0 & 13.2 & 7.41 & 681 & 1.70 & 73 \\
\hline 100 & 12.1 & 7.39 & 706 & 1.88 & 77 \\
\hline 300 & 10.1 & 7.37 & 737 & 2.10 & 83 \\
\hline 500 & 8.8 & 7.35 & 770 & 2.38 & 89 \\
\hline \multicolumn{6}{|c|}{ Third sample (after harvest) } \\
\hline 0 & 12.4 & 7.38 & 696 & 1.60 & 80 \\
\hline 100 & 11.5 & 7.36 & 718 & 1.80 & 87 \\
\hline 300 & 9.7 & 7.34 & 750 & 2.06 & 92 \\
\hline 500 & 8.3 & 7.31 & 790 & 2.25 & 99 \\
\hline
\end{tabular}

Table 4 Effect of Superphosphate treatments on some soil characteristics of Ras Sudr soil during and after growth season

\begin{tabular}{|c|c|c|c|c|c|}
\hline $\begin{array}{l}\text { Superphosphate } \\
\text { kg/fed. }\end{array}$ & $\begin{array}{l}\text { EC } \\
\left(\mathrm{dSm}^{-1}\right)\end{array}$ & pH & $\begin{array}{l}\text { Soluble } \mathrm{SO}_{4}{ }^{2-} \\
\left(\mathrm{mg} \mathrm{kg}^{-1}\right)\end{array}$ & $\begin{array}{l}\text { Available-P } \\
\left(\mathrm{mg} \mathrm{kg}^{-1}\right)\end{array}$ & $\begin{array}{l}\text { Available-K } \\
\left(\mathrm{mg} \mathrm{kg}^{-1}\right)\end{array}$ \\
\hline \multicolumn{6}{|c|}{ First sample (during the vegetative stage) } \\
\hline 200 & 11.8 & 7.41 & 666 & 1.65 & 62 \\
\hline 400 & 12.9 & 7.39 & 706 & 1.80 & 50 \\
\hline \multicolumn{6}{|c|}{ Second sample ( after flowering stage) } \\
\hline 200 & 10.8 & 7.40 & 705 & 1.92 & 84 \\
\hline 400 & 11.3 & 7.37 & 741 & 2.10 & 77 \\
\hline \multicolumn{6}{|c|}{ Third sample (after harvest) } \\
\hline 200 & 10.1 & 7.36 & 720 & 1.86 & 116 \\
\hline 400 & 10.8 & 7.33 & 757 & 2.06 & 88 \\
\hline
\end{tabular}

Table 5 Effect of irrigation periods treatments on some soil characteristics of Ras Sudr soil during and after growth season

\begin{tabular}{|c|c|c|c|c|c|}
\hline $\begin{array}{l}\text { Irrigation period } \\
\text { day }\end{array}$ & $\mathrm{EC}\left(\mathrm{dSm}^{-1}\right)$ & pH & $\begin{array}{l}\begin{array}{l}\text { Soluble } \mathrm{SO}_{4}{ }^{2-} \\
\left(\mathrm{mg} \mathrm{kg}^{-1}\right)\end{array} \\
\end{array}$ & $\begin{array}{l}\text { Available-P } \\
\left(\mathrm{mg} \mathrm{kg}^{-1}\right)\end{array}$ & $\begin{array}{l}\text { Available-K } \\
\left(\mathrm{mg} \mathrm{kg}^{-1}\right)\end{array}$ \\
\hline \multicolumn{6}{|c|}{ First sample (during the vegetative stage) } \\
\hline 7 & $8.65^{\circ}$ & 7.38 & 798 & 2.0 & 66 \\
\hline 14 & 12.1 & 7.40 & 679 & 1.7 & 57 \\
\hline 21 & 16.4 & 7.43 & 581 & 1.5 & 44 \\
\hline \multicolumn{6}{|c|}{ Second sample ( after flowering stage) } \\
\hline 7 & 8.18 & 7.36 & 852 & 2.2 & 88 \\
\hline 14 & 11.0 & 7.38 & 709 & 2.0 & 85 \\
\hline 21 & 14.0 & 7.40 & 610 & 1.75 & 69 \\
\hline \multicolumn{6}{|c|}{ Third sample (after harvest) } \\
\hline 7 & 7.56 & 7.33 & 866 & 2.18 & 96 \\
\hline 14 & 10.57 & 7.36 & 728 & 1.97 & 92 \\
\hline 21 & 13.4 & 7.38 & 622 & 1.73 & 80 \\
\hline
\end{tabular}

Soluble Sulphate $\left(\mathrm{SO}_{4}{ }^{2-}\right)$

Data in Table 3 shows that irrespective of irrigation periods and $\mathrm{P}$ application sulphur treatments progressively increased the soluble sulphate in the soil extract at each of the periods of wheat growth. The highest amounts of $\mathrm{SO}_{4}{ }^{2-}$ were obtained after harvest under different treatments of sulphur application. The increment in $\mathrm{SO}_{4}^{2-}$ at the different stages were $13 \%$,
$20 \%$ and $23 \%$ relative to 0 treatment of sulphur at the vegetative, after flowering and after harvesting could be attributed to the oxidation of sulphur which increased with time of cropping. Similar result was obtained by Naseem and Nasrallh (1983) who found that the rate of oxidation sulphur was increased from $60 \%$ after one week to $82 \%$ after four weeks. 
Similar trend was obtained by superphosphates as shown in Table 4. Increasing phosphate application increase $\mathrm{SO}_{4}{ }^{2-}$ in the soil solution because $\mathrm{PO}_{4}{ }^{3-}$ ions appear to decrease $\mathrm{SO}_{4}{ }^{2-}$ adsorption. In this respect Joshi et al., (1973) found that the $\mathrm{SO}_{4}{ }^{2-}$ has increased due to application of sulphur and phosphorus.

On the other hand, $\mathrm{SO}_{4}{ }^{2-}$ concentration proved to be decreased during irrigation periods as shown in Table 5 . However, it increases during growth season under different irrigation periods. These results indicate that the moisture content is a factor that can affect sulphur oxidation. In this respect Murakami (1968) found that oxidation of sulphur to sulphate was slow at low moisture content, rapid at $40 \%$ maximum water-holding capacity and most rapid at $64 \%$ of maximum capacity.

\section{Available Phosphorus}

Irrespective of irrigation periods and phosphorus application, Table 4 shows that sulphur treatments progressively increased the available phosphorus in the soil at extract at each period of wheat growth. The highest amounts of available phosphate were obtained from the highest sulphur treatment. The increment of available phosphorus in soil at different stages of wheat growth season was $52 \%, 72 \%$ and $53 \%$ relative to 0 sulphur treatment at the three stages, respectively. The decrease in soil content of available phosphate after harvesting may be due to high uptake of phosphorus by wheat plant. It is interesting to note that the increase of available phosphate in the soil was associated with the decrease in $\mathrm{pH}$ values at each period of soil sampling. This result may be due to that in calcareous soils inorganic phosphate as mostly bonded to $\mathrm{Ca}^{2+}$, and acidification of these soils facilitates the conversion of unavailable phosphorus to available form. In this respect, Kashirad and Bazargani (1972) reported that application of sulphur at all levels significantly reduced soil $\mathrm{pH}$ and increased available phosphorus of soil.

Phosphate treatments as shown in Table 4 increased available- $\mathrm{P}$ in the soil samples which were taken under different stages of wheat growth. The increments were $9 \%, 9.3 \%$ and $10.7 \%$ at vegetative flowering and after harvest stages, respectively. The increments were expected because the increase of superphosphate application with sulphur application will increase phosphate solubility. Similar conclusion was reported by Joshi et al., (1973).

On the other hand, irrigation periods, irrespective of other treatments decreased available $-\mathrm{P}$ by increasing water stress which increases the concentration of soil solution. It is known that $\mathrm{Ca}^{2+}$ ions were the dominant ions in soil solution of calcareous soils and subsequently will precipitate soluble phosphate to insoluble form. In this respect, Jacob et al., (1916) reported that low moisture content reduces water soluble phosphate.

\section{Available Potassium}

Irrespective of irrigation periods and phosphorus application, sulphur treatments increased the available$\mathrm{K}$ in soil at each period of wheat growth. These increments were $31 \%, 85 \%$ and $106 \%$ relative to 0 treatment of sulphur at the first, second and third stage, respectively. This result indicates that there is a positive relationship between the rates of sulphur oxidation and availability of $\mathrm{K}$ in soil. The sulphoric acid formed from sulphur oxidation will react with the primary minerals which contain $\mathrm{K}$ such as mica, lucite, orthoclase......etc, as well as the $\mathrm{K}$ adsorbed physically on the surface of $\mathrm{CaCO}_{3}$. Joshi and Seth (1975) reported that uptake of $\mathrm{K}$ has increased significantly due to the applications of phosphorus and sulphur.

On the other hand, phosphate treatments decreased the available $-\mathrm{K}$ in the soil samples which were taken at different stages of wheat growth as shown in Table 4 . However, the availability of $\mathrm{K}$ was increased by increasing the period of wheat growth. These increments were $43 \%$ and $82 \%$ in the soil samples taken after flowering and harvest stages, respectively.

Regarding the effect of water stress on the $\mathrm{K}$ availability, data in Table 4 shows that irrespective of other treatments, increasing water stress decreased the availability of $\mathrm{K}$ under different stages of wheat growth season. However, the available $-\mathrm{K}$ increased in soil samples taken after flowering and after harvest under different levels of moisture stress. The mean increments of available $-\mathrm{K}$ relative to vegetative stage were $55 \%$ and $71 \%$, after flowering and after harvest, respectively. This result may be due to that increasing period of sulphur application which increased the K availability.

\section{REFERENCES}

Abd-el Fattah, A.A. and Hilal, M.H. (1985). Effect of sulphur application on some properties of Egyptian desert soils. Proc. $2^{\text {nd }}$ Arab Regional Conf. on Sulphur and its Usages, 1:39-53.

Abdou A. S.; Fareed H. A.; Maher E. S.; Khaled A. E.; Sofian-Azirun, M. and Motior Rahman, M. (2011) Effects of elemental sulfur, phosphorus, micronutrients and Paracoccus versutus on nutrient availability of calcareous soils. Australian J. Crop Sci. 5 (5):554-561

Ahmed, A.I, Ali, O.M. and Matloub, M.A (2007). Effect of soil amendments on some physical and chemical properties of some soils of Egypt under saline irrigation water. African Crop Science Conference Proceedings Vol. 8. pp. 1571-1578 Beaker,K.W. (1980). Prakikums anweisung. Institute fur Bodenkunde, University Gottingen.

Dawood, F.A. ; Al-Omari, S.M. and Murtatha, N.S. (1985). High levels of sulphur affecting availability of some micronutrients in calcareous soils. J.Agric. Water Reso. Res. 4,2:149-160.

Heter, B. (1985). Utilization of sulphur for amendment of calcareous soil in Jordan. Proc. $2^{\text {nd }}$ Arab Regional Conf. on Sulphur and its Usages, 1:85-100.

Fatemeh H.; Parisa S.; Hassan S.V. and Hossein, B. (2012) Influence of Elemental Sulfur and Sulfur Oxidizing Bacteria on Some Nutrient Deficiency in Calcareous Soils. Intl J Agri. Crop Sci. Vol., 4 (12), 735-739.

Jackson, M.L. (1958). Soil Chemical Analysis. PrenticHall, Inc., Englewood Cliffs, N.J.U.S.A.

Jacob, G. Limpan: Director andC.Harry. Melean Chemist (1916). Sulphur oxidation in soils and its effect on the availability of mineral phosphates. Soil Sci,2:499-538. 
John, M. ; Jahangir,M. and Al-Mishal, M. (1985). Assessments of sulphur amendment affect on center pivot irrigation water quality in Saudi Arabia. $2^{\text {nd }}$ Arab Regional Conf. on Sulphur and its Usages, I:25-37.

Joshi,D.C.; Seth,S.D. and Pareek,B.L. (1973). Studies on sulphur and phosphorus uptake by mustard. J. Indian Soc.Soil. Sci., 21:2-167-172.

Joshi,D.C. and Seth,S.D. (1975). Effect of sulphur and phosphate application on soil characteristics, nutrient uptake and yield of wheat crop. J. Indian Soc.Soil. Sci., 23:2-217-221.

Kashird, A. and Bazarganil,J. (1972). Effect of sulphur on $\mathrm{pH}$ and availability of phosphorus in calcareous soil. Influence of sulphur and nitrogen on yield and chemical composition of corn. ZEITSCHRIFT FÜR PFLANZENERNÄHRUNG UND BODENKUNDE Volume 131, Issue 1, 1972, Pages: 6-13.

Marvin, E. Jensen (1975). Scientific irrigation scheduling for salinity control of irrigation return flows. EPA-600/2- 75-064. Nvember, 1975.

Murakami,H. (1968). The oxidation of oxidizable sulphur characteristics and importace of acid sulphate soil. J.Sci. Soil Manure Tokyo, 39:116-120. C.F. Soil and Fert. (1968) 31(6) (478).

Naseem, M.G. and Nasrallah, A.K. (1981). The effect of sulphur on the response of cotton to urea under alkali soil conditions in pot experiments. Plant and Soil, 62: 255-263.

Ogata, G. and Bower, C.A. (1965). Significance of biological sulphate reduction in soil salinity. Soil sci. Soc. Amer. Proc. 29:23-25.
Piper, C.S. (1950). Soil and Plant Analysis. Inter.Sci. Publ.Inc., New York.

Pupisky, H. and Shainberg, I. (1979). Salt effect on the hydraulic conductivity of sandy soil. Soil Sci. Soc. Amer. J., 43: 429-433.

Reda, M. and Modaihishi, A.S. (1990). Gypsum formation in sulphur treated soils. Arab Gulf Journal of Scientific Research, Arab Gulf J. Scient. Res. 8: 79-91

Richards, L.A. (Editor) (1954). Diagnosis and Improvement of Saline and Alkali Soils. U.S.Dept. Agric. Hand book No.60.

Rhoades, J.D. and Ingvalson, R.D. (1969). Macroscopic swelling and hydraulic conductivity properties of four vermiculatic soils. Soil Sci. Soc. Amer. Proc., 33:364-369.

Ryden, J.C., Syers, J.K and Tillman, R.W. (1987). Inorganic anion sorption and interaction with phosphate sorption by hydrous ferric oxide gel. Journal of Soil Science, 38: 211-217.

Shadfan, H. and Hussen, A.A. (1985). Effect of sulphur application on the availability of $\mathrm{P}, \mathrm{Fe}, \mathrm{Mn}, \mathrm{Zn}$, and $\mathrm{Cu}$ in selected Saudi Soils. Proc. $2^{\text {nd }}$ Arab Regional Conf. on Sulphur and its Usages, 1:3-23.

Spencer, K. and Freney, J.R. (1960). A comparison of several procedures for estimating the sulphur status of soil. Aust.J.Agric. Res. 11:948-959.

Stromberg, L.K. and Tisdal, S.L. (1979). Treating irrigated arid-land soils with acid- forming sulphur compounds. Technical Bulletin Number 24. The Sulphur Institute, Washington, D.C. 20006.

\footnotetext{
أثر اضافة الكبريت وملوحة مياه الري على الخواص الكيميائية للتربة الجيرية برأس سدر، جنوب سيناء ، مصر 